\title{
Prolonged Somatic Transposition in Citrus: The Autonomous Ac Transposable Element Remains Active in the Citrus Genome for Several Years
}

\author{
Taly Trainin \\ Department of Fruit Culture, Newe-Ya'ar Research Center, Agricultural Research Organization, P.O.B. \\ 1021, Ramat Yishay 30095, Israel
}

Alexander Lipsky
Department of Ornamental Horticulture, The Volcani Center, P.O.B. 6, Bet Dagan 50250, Israel

Avraham A. Levy

Department of Plant Sciences, The Weizmann Institute of Science, Rehovot 76100, Israel

Doron Holland ${ }^{1}$

Department of Fruit Culture, Newe-Ya'ar Research Center, Agricultural Research Organization, P.O.B. 1021, Ramat Yishay 30095, Israel

\begin{abstract}
AdDitional INDEX wORDs. transposable elements, Citrus paradisi, transposon display, transformation, fruit trees, genetic polymorphism

Abstract. The maize transposable element Activator $(A c)$ has been shown to be active in a number of dicots, including arabidopsis [Arabidopsis thaliana (L.) Heynh.], tobacco (Nicotiana tabacum L.), tomato (Lycopersicon esculentum Mill.), potato (Solanum tuberosum L.), and aspen (Populus tremuloides Michx.). However, no information is available on somatic transposition in any plant during several years of growth and development. It is not known how transposition affects genetic variability among vegetative parts that have developed during a long period of growth. In order to explore the possibility of using somatic $A c$ transposition for gene tagging and mutagenesis in fruit trees, a derivative of the maize $A c$ transposable element was introduced into 'Duncan' grapefruit (Citrus paradisi Macf.) by Agrobacterium tumefaciens (Smith \& Towns.) Conn.-mediated stable transformation. Genetically identical 4-year-old sibling trees were established by grafting one of the transformants on Troyer citrange [Citrus sinensis (L.) Osbec. $x$ Poncirus trifoliate (L.) Ras.] rootstocks. We demonstrated that the Ac element was active upon transformation in citrus (Citrus L.) trees and that transposition can create genetic variability among tree siblings and among leaves collected from different parts of the same tree. $A c$ was still active among propagated plants 4 years after transformation, clearly indicating that it is capable of maintaining itself in citrus trees for a long period of time. The observation of different integration patterns in different parts of the same tree and within tree siblings originating from the same transformant suggests that an $A c$-based mutagenesis system could be very useful in creating somatic mutations in citrus trees.
\end{abstract}

Breeding fruit trees is a long-term, tedious, and costly process. Unlike vegetable crops or other perennial crops, woody perennials require a long juvenile period for flowering. Most fruit trees are highly heterozygous and the lack of genetically "pure" varieties makes genetic crosses impractical. Due to these problems, fruit tree genetics and breeding are less advanced than in other plant crops. Modern genomic approaches could be very useful in outlining the possible involvement of groups of genes in many processes that have strong implications for agriculture, such as in fruit development, stress resistance, and fruit yield. cDNA libraries and consequent production of expressed sequence tag (EST) data on several fruit trees are now available for a wide array of fruit trees. However, unequivocal assignment of a physi-

Received for publication 2 Oct. 2003. Accepted for publication 3 Mar. 2004 We thank Mr. Abraham Elhanati for his help in grafting the citrus trees, and Dr. Vitali Portnoy for his assistance with AFLP reactions. This project was partially supported by the Chief Scientist of the Ministry of Agriculture and Rural Development of Israel and by the Citrus Marketing Board of Israel.

1To whom reprint requests should be addressed.E-mail address: vhhollan@agri. gov.il ological function to genes requires the development of efficient reverse and forward genetics methodologies, such as tagged mutant analysis. Transposon mutagenesis is one of the naturally occurring mechanisms that can be used to identify mutants in genes of interest. Many species of plants were found to contain naturally occurring transposable elements. The maize (Zea mays L.) -derived $A c$ transposon mutagenesis system is one of the best known systems for gene tagging. Derivatives of $A c$ transposable elements were produced for various purposes and $A c$ was shown to transpose in heterologous plant systems (Baker et al., 1986; Kunze and Weil, 2002; Martiessen, 1998; Meissner et al., 2000; Pereira, 2000; Van Sluys et al., 1987; Yoder et al., 1988). Ac transposition was also reported for aspen, and somatic transposition was demonstrated to occur in these plants at a relatively high frequency (Ebinuma et al., 1997; Fladung and Ahuja, 1997; Kumar and Fladung, 2003). A potential feature of transposon mutagenesis, which makes it particularly attractive for utilization in trees, is its continuous nature, generating somatic variation that can be exploited in tree breeding. Unless silenced, e.g., as a result of cytosine methylation, an intact transposon introduced into a plant will keep transposing and generating mutations for 
many years. This somatic instability can be exploited by turning a few transformed trees into "mutation machines" that can produce the stems necessary for vegetative propagation and generation of a population of mutants. Such a feature would be particularly valuable for mutagenesis in woody perennials that live for many years and are usually difficult to transform. However, despite these advantages, to our knowledge, a follow-up of transposition events along developing branches within the same tree for several years has not been done. In this study we have assessed the utility of transposons as "perennial mutagen" in citrus. We report for the first time the introduction and stable transformation of an $A c$ derived transposable element into a citrus fruit tree. Moreover, we followed the proliferation of $A c$ elements over a period of 4 years and demonstrated that $A c$ remains active in citrus tissues for at least 4 years and transposes efficiently, yielding substantial variability among different parts of the tree.

\section{Materials and Methods}

Citrus transformation and establishment of transgenic PLANTS FROM IDENTICAL ORIGIN. Citrus transformation was done as described by Luth and Moore (1999) and Peña et al. (1996). Stem cuts from sterile 'Duncan' nucellar seedlings were immersed in Agrobacterium tumefaciens (EHA105) solution harboring plasmid $p A c G$ (Finnegan et al., 1989). Plants were regenerated on kanamycin as described by Luth and Moore (1999). Leaves from the regenerated plants were analyzed for GUS expression (Jefferson et al., 1987). Instead of rooting, regenerated explants were grafted on stems of 'Duncan' seedlings that were germinated in sterile conditions. After several months, buds developed from one individual of the grafted explants were used as a source for a second graft on Troyer citrange rootstocks. Second grafting was done by eye-grafting buds from a single transgenic plant on Troyer citrange rootstocks. In this way 12 'Duncan' transgenic plants originating from a single transformant plant were produced.
Plant material and DNA Preparation. DNA was extracted from leaves of transgenic 'Duncan' plants. For DNA preparation leaves were harvested from different siblings or from different branches of each sibling (pools of four to five leaves per branch). Leaves from intact 'Duncan' trees grown in the orchards of the Agricultural Research Center in Bet Dagan were used as controls. Leaves were frozen in liquid nitrogen and stored at $-70{ }^{\circ} \mathrm{C}$ for further use. DNA was isolated from leaves using the CTAB (hexadecyl-trimethylamoniumbromide) method (Murray and Thompson, 1980).

PCR PROCEDUREs. For most reactions PCR was performed in a total volume of $25 \mu \mathrm{L}$ containing $10-20 \mathrm{ng}$ of genomic DNA, $0.4 \mu \mathrm{M}$ of each primer, 0.02 units REDTAQ DNA polymerase (Sigma-Aldrich Corp., St. Louis), $200 \mu \mathrm{M}$ of each dNTP, 1X PCR reaction buffer and $1.6 \mathrm{~mm} \mathrm{MgCl}_{2}$. DNA amplification was carried out in a PTC-150 Minicycler (MJ Research, Watertown, Mass.) or in iCycler Thermal PCR system (Bio-Rad Laboratories, Hercules, Calif.). An initial denaturation step of 2 min at $94{ }^{\circ} \mathrm{C}$ was followed by 30 cycles comprising $1 \mathrm{~min}$ at $94{ }^{\circ} \mathrm{C}, 1 \mathrm{~min}$ at 50 to $60^{\circ} \mathrm{C}$ (different for each primer pair), and 1 min at $72^{\circ} \mathrm{C}$. An additional cycle of $7 \mathrm{~min}$ at $72{ }^{\circ} \mathrm{C}$ was used for final extension. Amplification products were separated by electrophoresis in agarose gels and stained with ethidium bromide. The 100base pair (bp) ladder (MassRuller DNALadder, low range; MBI Fermentas, Burlington, Ont., Canada) was used as a size marker. Primers and sequences used are presented in Table 1.

Southern ANALYSIS. Total genomic DNA was digested with restriction enzyme HindIII and separated on agarose gel (Sambrook et al., 1989). Gene Screen Plus membranes (DuPont, NEN Research Products, Boston) were used for blotting and hybridization was performed according to supplier instructions. Prehybridization and hybridization were done according to Sambrook et al. (1989). Probes were labeled with $\left({ }^{32} \mathrm{P}\right) \mathrm{dCTP}$ using the REDIPRIME II kit (Amersham Biosciences UK Ltd., Buckinghamshire, U.K.). Hybridization was carried on at $65^{\circ} \mathrm{C}$.

Table 1. List of primers used in this work. The 35S promoter, uidA gene and the Ac element are as described for $p A c G$ (Finnegan et al., 1989). Primer positions are indicated separately for each of the genetic components.

\begin{tabular}{|c|c|c|c|c|}
\hline $\begin{array}{l}\text { Primer } \\
\text { name }\end{array}$ & Primer location & Primer sequence & $\begin{array}{l}\text { Expected amplificaton } \\
\text { product size }\left(\mathrm{bp}^{\mathrm{z}}\right)\end{array}$ & Remarks \\
\hline $\begin{array}{l}\text { uidA forward } \\
\text { uidA reverse }\end{array}$ & $\begin{array}{l}\text { uidA gene (1812 bp), } 130-152 \\
\text { uidA gene, } 1172-1148\end{array}$ & $\begin{array}{l}5^{\prime} \text {-gcaattgctgtgccaggcagttt-3' } \\
5^{\prime} \text {-ctgtaagtgcgettgctgag-3' }\end{array}$ & $\begin{array}{l}1042 \\
1042\end{array}$ & $\begin{array}{l}\text { Fig. 3, uidA probe } \\
\text { Fig. 3, uidA probe }\end{array}$ \\
\hline uidA reverse & uidA gene, $1172-1148$ & $5^{\prime}$-ctgtaagtgcgettgctgag-3' & $\begin{array}{l}\text { After } A c \text { excision: } 1591 ; \\
\text { before } A c \text { excision: } 6156\end{array}$ & Fig. 4, PCR \\
\hline $35 S$ forward & $35 \mathrm{~S}$ promoter $(419 \mathrm{bp}), 1-20$ & $5^{\prime}$-aacatggtggagcacgacac- $3^{\prime}$ & $\begin{array}{l}\text { After } A c \text { excision: } 1591 \text {; } \\
\text { before } A c \text { excision: } 6156\end{array}$ & Fig. 4, PCR \\
\hline$A c 1^{\prime}$ & Ac element, 985-965 & $5^{\prime}$-gaggaatggagtcgtagccg-3' & 847 & Fig. 3, Ac probe \\
\hline Ac138 & Ac element, $138-157$ & $5^{\prime}$-cggaaacggaaacggtagag-3' & 847 & Fig. $3, A c$ probe \\
\hline $\begin{array}{l}A c 1 \\
A c 2\end{array}$ & $\begin{array}{l}\text { Ac element, } 965-985 \\
\text { Ac element, } 1258-1240\end{array}$ & $\begin{array}{l}5^{\prime} \text {-cggctacgactccattcctc-3' } \\
5^{\prime} \text {-tgaatccgactagaagag- } 3^{\prime}\end{array}$ & $\begin{array}{l}293 \\
293\end{array}$ & $\begin{array}{l}\text { Fig. 7, RT-PCR } \\
\text { Fig. 7, RT-PCR }\end{array}$ \\
\hline TAc 44 & Ac element, 44-22 & $5^{\prime}$-gataacggtcggtacgggatttt- $3^{\prime}$ & --- & Transposon display \\
\hline TAc 126 & Ac element, 126-104 & $5^{\prime}$-gtatatccegtttccgttccgtt-3' & --- & Transposon display \\
\hline MseI primer & --- & $5^{\prime}$-gacgatgagtcctgagtaa-3' & --- & Transposon display \\
\hline BamHI adapter & --- & $\begin{array}{l}5^{\prime} \text {-tcgtagactaagtacat-3' and } \\
5^{\prime} \text {-gatcatgtacttagtctac-3' }\end{array}$ & --- & Transposon display \\
\hline MseI adapter & --- & $\begin{array}{l}5^{\prime} \text {-gacgatgagtcctgag-3' and } \\
5^{\prime} \text {-tactcaggactcat-3' }\end{array}$ & --- & Transposon display \\
\hline$T d s f 1$ & Fragment-specific internal primer & $5^{\prime}$-ttgccaacttcaagggactc- $3^{\prime}$ & --- & Fig. 5B, PCR \\
\hline
\end{tabular}

$\mathrm{zbp}=$ base pairs. 
The following PCR products were used as probes: 1) for the uidA gene, a 1042 bp probe was synthesized using uidA forward and uidA reverse primers (see Table 1);2) for the Ac element, a 847 bp fragment of DNA was synthesized using Ac138 and Acl' primers.

Transposon DisPlay. DNA samples (100 ng) were digested with $\mathrm{BamHI}$ and $\mathrm{MseI}$ by incubation for $18 \mathrm{~h}$ at $37^{\circ} \mathrm{C}$ (five units of each enzyme, $2 \mathrm{X}$ MBI fermentas $\mathrm{y}+$ /tango buffer in a final volume of $30 \mu \mathrm{L}$ ). Restriction enzymes were inactivated by incubation at $65^{\circ} \mathrm{C}$ for $15 \mathrm{~min}$. Each sample was then dialyzed on Millipore VSWP 0.025- $\mu \mathrm{M}$ cellulose filters (Millipore, Billerica, Mass.) for 30 min to allow change of buffer. A specific Ac adapter was designed to ligate to a unique $\mathrm{BamHI}$ site situated 182 bp from the 5' end of the Ac element (Fig. 5C). MseI does not cut between the $5^{\prime}$ end of the Ac element and the BamHI site. Adapters were ligated by adding $10 \mu \mathrm{L}$ of ligation mix ( 5 pmole BamHI adapter, 50 pmole $\mathrm{MseI}$ adapter, $4 \mu \mathrm{L} 10 \mathrm{X}$ ligation buffer with ATP and three units T4 ligase) and further incubation for $3 \mathrm{~h}$ at $25^{\circ} \mathrm{C}$. The preamplification reaction was carried out using the MseI primer in combination with an $A c$-specific primer positioned 126 bases from the Ac $5^{\prime}$ end (primer TAc126, see Fig. 5C). Five microliters of 1:10 diluted ligation reaction were mixed with 10 pmole $M s e I$ primer, 2 pmole Tac126 primer, 0.2 mu dNTP's, 5X GC rich solution and 0.5 unit Taq polymerase (FastStart Taq, Roche Applied Science, Mannheim, Germany) in 10X PCR buffer containing $20 \mathrm{~mm} \mathrm{MgCl}_{2}$ in a final volume of 20 $\mu \mathrm{L}$. The resulting PCR products were diluted 1:20. In the second, radioactive PCR reaction, an additional $A c$-specific primer positioned 44 bases from the Ac 5' end (primer Tac44, see Fig. 5C) was used in combination with the MseI primer. Five microliters of the diluted preamplified material were used as a template for amplification by mixing with 5 pmole $M s e I$ primer, 1 pmole labeled TAc44 primer, $0.2 \mathrm{~mm}$ dNTPs, $5 \mathrm{X}$ GC rich solution and 0.5 unit Taq polymerase (FastStart Taq, Roche) in 10X PCR buffer. Parallel reactions with only one of the primers were performed as controls. All PCR amplifications were carried out in the iCycler Thermal PCR system (Bio-Rad). An initial denaturation step of 4 min at $94{ }^{\circ} \mathrm{C}$ was followed by three cycles of $30 \mathrm{~s}$ at $94{ }^{\circ} \mathrm{C}, 30$ $\mathrm{s}$ at $70{ }^{\circ} \mathrm{C}$, and $1 \mathrm{~min}$ at $72{ }^{\circ} \mathrm{C} ; 13$ cycles of $30 \mathrm{~s}$ at $94{ }^{\circ} \mathrm{C}, 30 \mathrm{~s}$ at $65^{\circ} \mathrm{C}$ with a decrement of $0.7^{\circ} \mathrm{C}$ each cycle, and $1 \mathrm{~min}$ at $72{ }^{\circ} \mathrm{C}$; and 23 cycles of $30 \mathrm{~s}$ at $94^{\circ} \mathrm{C}, 30 \mathrm{~s}$ at $56^{\circ} \mathrm{C}$, and $1 \mathrm{~min}$ at $72^{\circ} \mathrm{C}$. For 20 PCR reactions the $5^{\prime}$ ends of 20 pmole of Tac 44 primer were labeled with 10 units of T4 polynucleotide kinase and $2 \mu \mathrm{L}$ $\left[\gamma-{ }^{33} \mathrm{P}\right] \mathrm{ATP}(50 \mu \mathrm{Ci})$ in a final volume of $10 \mu \mathrm{L}$ by incubation at 37 ${ }^{\circ} \mathrm{C}$ for $1 \mathrm{~h}$. The kinase was inactivated by heating at $85^{\circ} \mathrm{C}$ for 15 min. For gel analyses $3 \mu \mathrm{L}$ of PCR reaction solution was loaded on $6 \%$ denaturing polyacrylamide gels. Interesting bands were excised from gel, immersed in $50 \mu \mathrm{L}$ of water, and incubated at 4 ${ }^{\circ} \mathrm{C}$ for at least $1 \mathrm{~h}$. Three microliters were then subjected to PCR with primer TAc44 in combination with the MseI primer. Cloning was performed with InsT/Aclone PCR Product Cloning Kit (MBI Fermentas). Cloned products were sequenced. A specific internal primer was chosen from the genomic portion of the sequenced fragment (see Table 1). This primer was used in combination with TAc44 to amplify the specific fragment using genomic DNA as a template (PCR conditions: same as for transposon display reaction). Adapters and primers used for the transposon display are shown in Table1.

RNA ISOLATION AND RT-PCR. Total RNA was isolated from leaves of a 4-year-old tree by the method described by Seidman and Struhl (1987). Total RNA was used as a template for first strand cDNA synthesis using reverse transcriptase (SuperScript
II RNase H-Reverse Transcriptase, Invitrogen Life Technologies, Carlsbad, Calif.) and oligo $\mathrm{d}(\mathrm{T})_{15}$, according to manufacturers' instructions. cDNA was then used as a template for a PCR reaction with specific $A c$ primers $A c 1$ and $A c 2$ (see PCR procedures and Table 1).

\section{Results and Discussion}

Citrus transformation and establishment of 'Duncan' SIBLINGS ORIGINATING FROM IDENTICAL GENETIC BACKGROUND. Transformed explants were stained for GUS activity. Blue sectors should appear if $A c$ excision occurred in the transformants, thus enabling expression of the uidA gene under the control of the $35 \mathrm{~S}$ promoter ( $p A c G$, Finnegan et al., 1989). Several patterns of GUS expression were observed in the developing 'Duncan' explants (Fig. 1). We interpret the differences in sector shape and size as differences in the timing of the excision event during the development of the newly formed transformants. If transposition occurred early in transformation, the entire leaf is expected to be blue (Fig. $1 \mathrm{~B}$ and D). However, if transposition occurred relatively late after transformation, small sectors should be visible, such as in Fig. 1A. Leaves from wild-type 'Duncan' do not stain (Fig. 1C). We also transformed 'Duncan' grapefruit with a control construct containing a 35S-GUS fusion. Leaves of such plants stain uniformly in a pattern similar to Fig. 1D (data not shown). We chose a single transformant that displayed whole leaf GUS staining (Fig. 1D) for further experiments. To overcome difficulties in rooting of the transformed explants, the original transformant was grafted on 'Duncan' seedlings (Fig. 2). When the scion of the plant grew enough, bud-eyes from the plant were grafted on 12 Troyer citrange rootstock seedlings. In this way we established 'Duncan' sibling plants that originated from a genetically identical source. The resulting plants were further characterized at the molecular level.

PCR ANAlysis FOR THE DETECTION OF EXCISION EVENTS. PCR analysis was done using primers originating from either side of the transposon as illustrated in Fig. $3 \mathrm{~A}$ and $\mathrm{B}$ : one primer
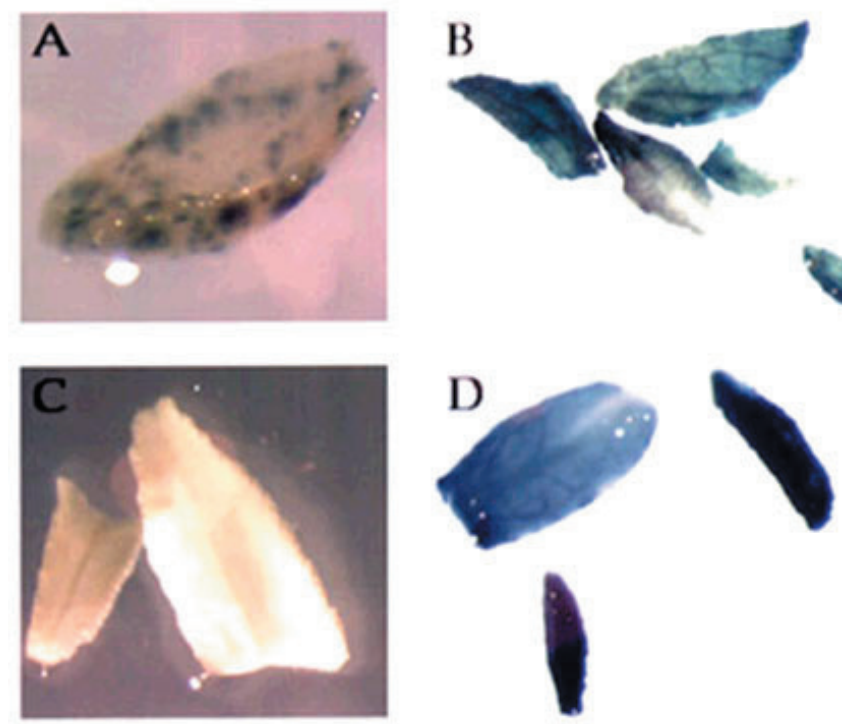

Fig. 1. GUS patterns from transgenic 'Duncan' grapefruit explants: $(\mathbf{A}, \mathbf{B}, \mathbf{D})$ leaves from different transgenic 'Duncan' plants transformed with $p A c G ;(\mathbf{C})$ leaves from wild-type 'Duncan'. 

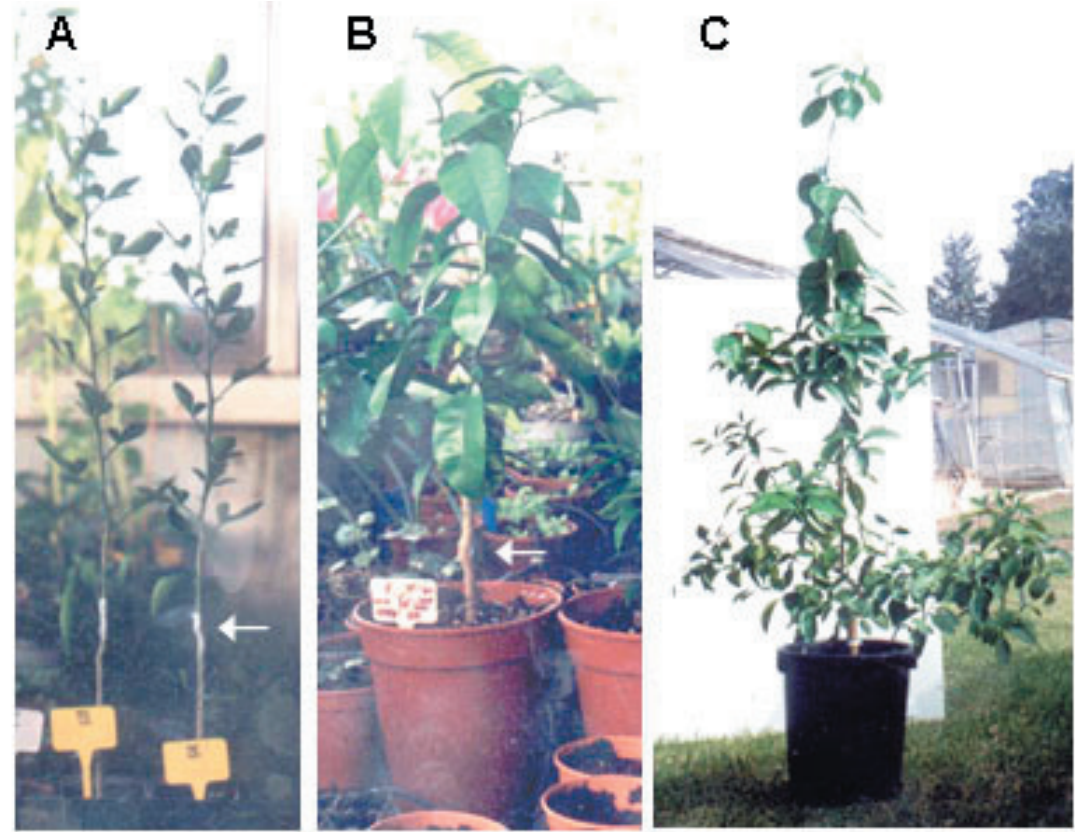

Fig. 2. Establishment of transgenic trees from initial 'Duncan' grapefruit transformant plant: (A) eye grafting of transgenic buds on Troyer citrange rootstocks; (B) 7-month-old grafted transgenic 'Duncan' plant; (C) 3-year-old transgenic 'Duncan' tree.

A

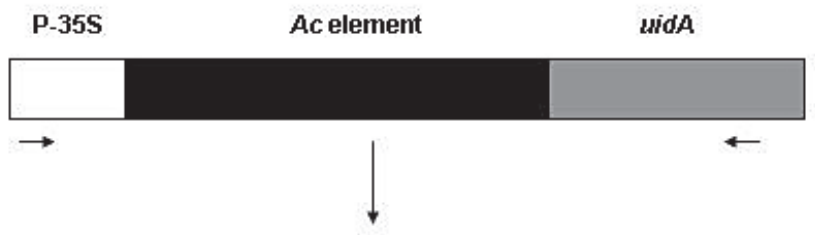

Ac excision

B

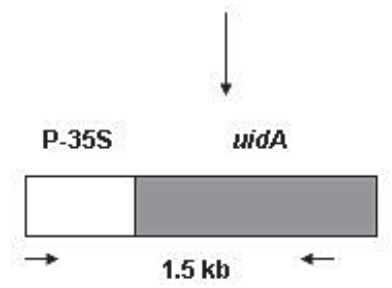

c

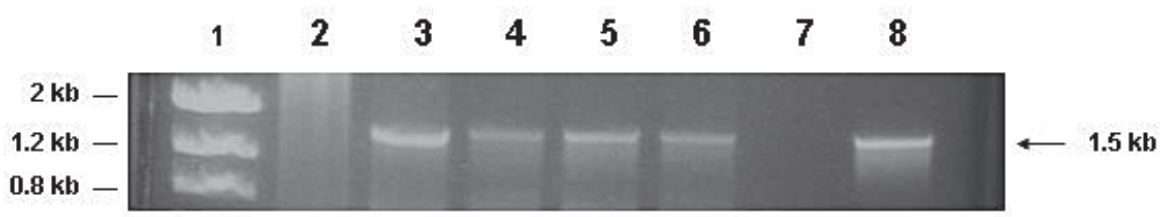

Fig. 3. PCR analysis for identification of excision of the Ac element in 'Duncan' grapefruit transgenic plants: $(\mathbf{A}, \mathbf{B})$ schematic drawing showing the relative position of the $35 \mathrm{~S}$ promoter and the uidA gene before and after transposition. Darkened black area: location of the Ac element. Gray area: uidA gene. Open box: $35 \mathrm{~S}$ promoter. Arrows represent primers used for PCR analysis (uidA reverse and $35 S$ forward). The relative positions of the primers before and after the excision are presented. (C) PCR analysis of DNA extracted from citrus plants with the primers indicated by arrows in A, B: (1) DNA size markers (low mass ladder Gibco-BRL; (2) DNA extracted from a non-transformed 'Duncan' plant; (3-6) DNA extracted from transgenic 'Duncan' plants transformed with $p A c G$; (7) control, PCR with no DNA; (8) plasmid DNA containing the uidA fused to the $35 \mathrm{~S}$ promoter $(p B I 121)$. originating from the $35 \mathrm{~S}$ promoter (primer $35 \mathrm{~S}$ forward) and a second primer from the uidA gene (primer uidA reverse). If an excision event happened, then a band of $\sim 1.5$ kilobases $(\mathrm{kb})$ should be obtained. The data (Fig. 3C) clearly corroborate the GUS staining data and indicate that $A c$ is actively excising in all of the tested plants.

SOUTHERN ANALYSIS FOR CONFIRMATION OF TRANSFORMATION AND FOR DETECTION OF POLYMORPHIC CHANGES WITHIN 'DUNCAN' SIBLINGS. Southern analysis using a probe that contains part of the transposable element and using the HindIII restriction enzyme demonstrates that all of the analyzed transformants contain the gene, and some polymorphism is observed (Fig. 4B). This is expected because the probe and restriction enzymes were designed to detect chromosomal flanking regions. As can be seen in the schematic presentation (Fig. 4A), HindIII cuts twice in the Ac element (at nucleotides 1784 and 3390). Therefore, in order to detect polymorphism, a probe originating from the $A c$ element's 5' end was used. This probe is expected to hybridize to a $2.6 \mathrm{~kb}$ fragment in plasmid $p A c G$ and in the T-DNA before $A c$ excision. After $A c$ excision a different hybridization pattern should be observed, depending on the nearest HindIII site in the new integration site. As can be seen in Fig. 4B in three of the four siblings analyzed, the probe hybridized to a $2.3 \mathrm{~kb}$ fragment. In one sibling, a different pattern was obtained, with probe hybridization to two different fragments, sized 4.1 and 1.8 $\mathrm{kb}$ in length. These data demonstrate both that the plants are transgenic and that $A c$ has transposed from the T-DNA to a new position in the genome. Plants 3,4 , and 6 originated from the same transposition event while plant 5 is derived from a clone with a different transposition (Fig. 4B). Note that later somatic transposition events are probably present in the analyzed tissues but cannot be detected by DNA blotting analysis.

Southern analysis using the uidA gene as a probe clearly demonstrated that all of the analyzed plants contain the gene (Fig. 4C). No signal was obtained from DNA extracted from nontransformed plants (data not shown). Although it appears that the size of the GUS specific band slightly differs in size, PCR experiments with GUS specific primers (data not shown) indicated no difference in sizes among the four plants tested in Fig. 4C.

TRANSPOSON DISPLAY ANALYSIS FOR THE DETECTION OF AC INSERTIONS WITHIN THE CITRUS GENOME. Due to the somatic nature 
Fig. 4 (right). Southern analysis of transgenic 'Duncan' grapefruit plants: (A) a schematic drawing indicating the relative position of the $A c$-specific probe within the $A c$ element. Darkened area: location of the transposase gene. (B) Southern hybridization with $A c$-specific probe: (1) positive control. pAcG digested with HindIII; (2) wild-type 'Duncan' DNA digested with HindIII; (3-6) transgenic 'Duncan' plants digested with HindIII.(C) Hybridization of the same samples as in B but with the uidA (GUS) -specific probe. Band size, $4.6 \mathrm{~kb}$. Band sizes correspond to $\lambda /$ HindIII size marker.

of the transposition events, we expected insertion events to occur only within certain plant segments or sectors of the transformed plants. In order to identify insertion sites with such characteristics within the citrus genome, it was essential to utilize a highly sensitive detection method. Modified AFLP methods in which one of the AFLP primers corresponds to a region located at one of the ends of the transposable element have been successfully utilized to examine the distribution, abundance, and levels of activity of several transposable elements (Casa et al., 2000; Van den Broeck et al., 1998).

In this study we employed an AFLP-based method, termed "transposon display," for detection of Ac transposition in our system. Our protocol is based on a unique BamHI site located at 182 bp from the $5^{\prime}$ end of the Ac element (Fig. 5C). Genomic DNA was digested with $\mathrm{BamHI}$ and $\mathrm{MseI}$ and ligated to corresponding adapters. Two $A c$-specific primers upstream of the BamHI site
$\mathbf{A}$

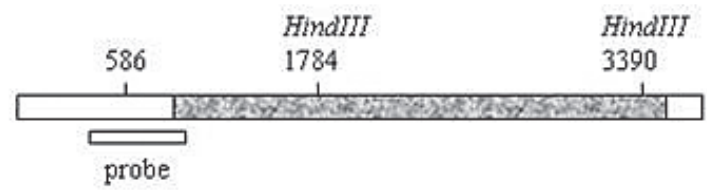

Ac element

B

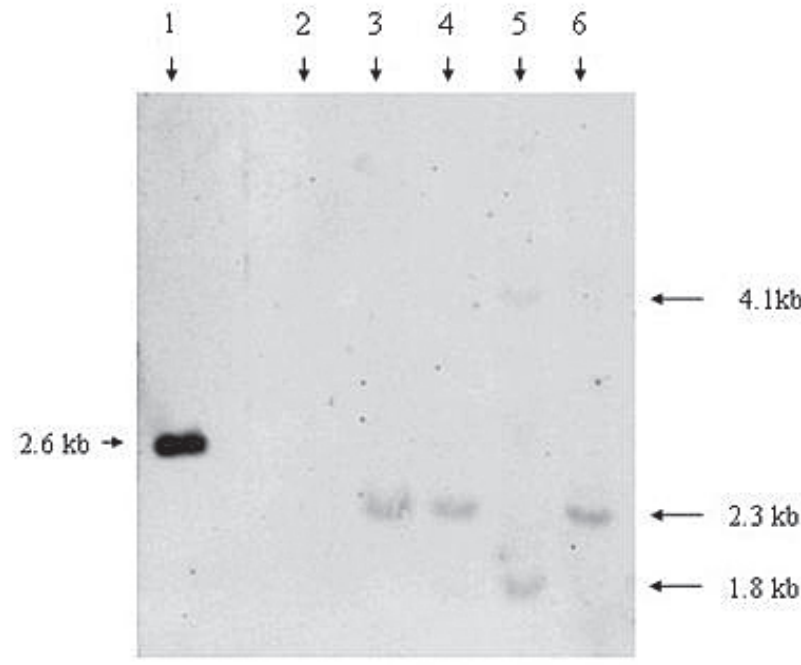

C

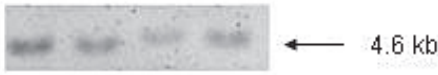

B

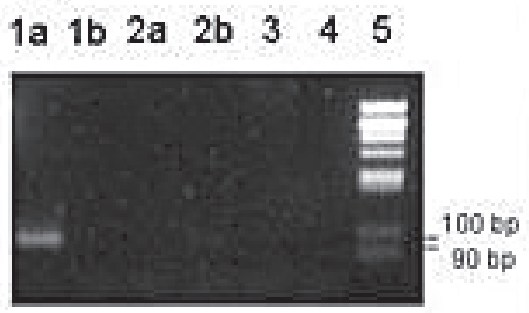

A
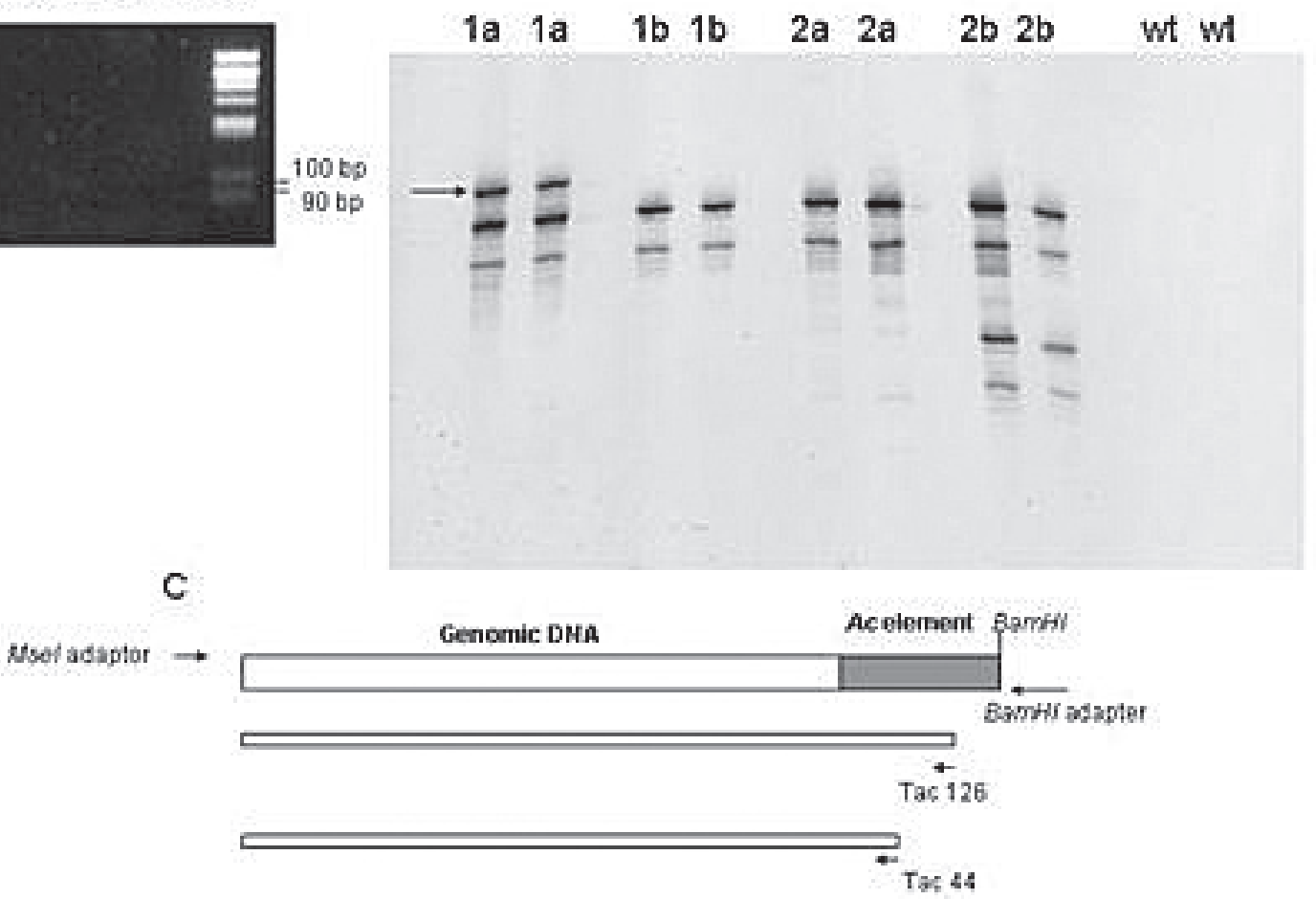

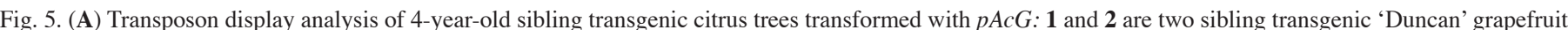

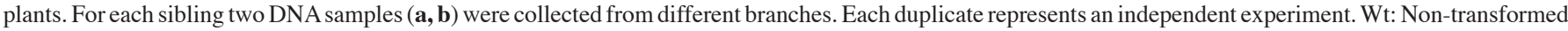
'Duncan' plants. (B) Confirmation of transposon display data by subsequent PCR analysis with specific primers based on a sequenced fragment from 1a (indicated by an arrow in A). 1a, 1b; 2a, 2b are identical to DNA samples in A. (3) Non-transformed 'Duncan' plants; (4) no DNA control; (5) size marker: pBR322 DNA/ alu1 marker ( 90 and 100 bp bands are indicated). Primers used in B are Tdsf1 (fragment specific internal primer) and TAc44 (see Table1 for details of the primers). (C) Schematic presentation of the strategy used for transposon display analysis. TAc126 and TAc44 are two specific primers utilized for successive amplifications. Narrow open boxes represent resulting PCR products. 
were synthesized for use in subsequent PCR reactions (Tac126 and Tac44 positioned 126 or 44 bases from the Ac element 5' end, respectively (Fig. 5C). PCR reactions were carried on using specific Ac primers in combination with the MseI primer (Vos et al., 1995). In order to increase specificity the first PCR reaction was performed using TAc126 as the specific Ac primer while in the second, radioactive PCR reaction, TAc 44 was used. A pattern consisting of several bands was obtained only for DNA originating from transgenic plants (Fig. 5A). No bands were observed in control nontransformed 'Duncan' lanes (Fig. 5A). This data clearly indicated extensive $A c$ insertion events and obvious variability among sibling plants with respect to $A c$ insertions. As can be seen in Fig. 5A, all transgenic DNA samples have a common basic banding pattern, but each sample also has its unique bands. Common bands probably represent primary excision/insertion events, while unique bands most likely represent excision/insertion events specific to each of the siblings. Furthermore, different banding patterns were observed not only for different siblings (1a and $1 \mathrm{~b}$ vs. $2 \mathrm{a}$ and $2 \mathrm{~b}$ ) but also within different branches of the same tree (1a vs. 1b; 2a vs. 2b). Specificity of transposon display results was also confirmed by further PCR analyses. Bands that appeared to be specific for a certain sibling or for a certain part of the same tree were excised, cloned, and sequenced. For each of the sequenced fragments a specific internal primer was chosen from the genomic portion of the fragment. This primer was used in combination with an $A c$-specific primer to amplify genomic DNA extracted from the transgenic trees. As expected, amplified products were observed only from the trees that specifically displayed the AFLP fragment (data not shown for all trees or fragments). One example of such an experiment is shown in Fig. 5B. A 90-100 bp fragment that appears only in tree 1, branch a, in transposon display (Fig. 5A) was obtained by PCR analysis using a specific primer as discussed above.

Since the transposon display was done on 4-year-old plants, the differences within the plants are the best indication that the transposon is still active after several years. Furthermore, RT-PCR analysis done on 4year-old transgenic plants indicates that trancription of $A c$ transposase still occurs in such plants (Fig. 6; data not shown for all plants). The dynamic nature of the transposon may lead to a bias in the evaluation of the rate of transposition because the methodology used in this study can only detect current insertion sites but not those sites where the transposon was initially inserted and moved away. In addition, if transposition occurred in tiny sectors, the ability to detect insertions could be well under the detection sensitivity of the transposon display method. We therefore predict that the number of transposition events that actually occur in citrus is much higher than what is observed in our experiments.

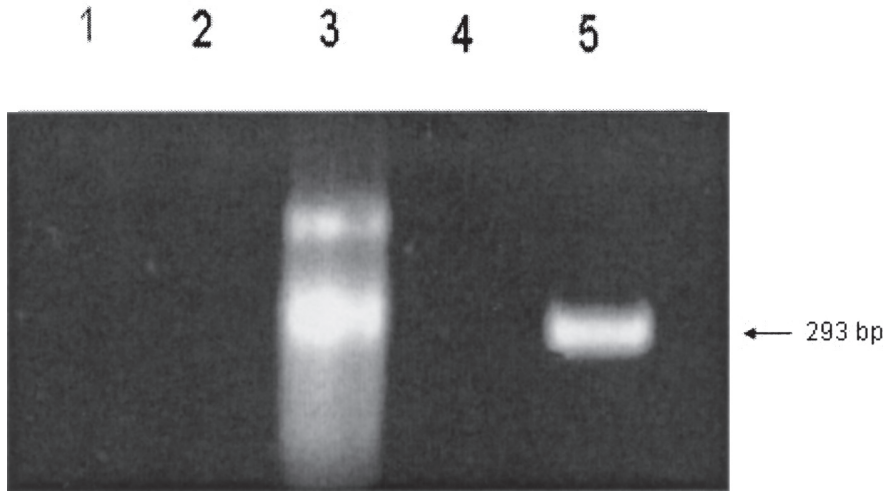

Fig. 6. RT-PCR analysis for the detection of transposase transcription in 4-yearold transgenic citrus trees transformed with $p A c G$ : (1) no DNA; (2) PCR with total RNA before reverse transcriptase; (3) RT-PCR product of a 4-year-old transgenic tree transformed with $p A c G$; (4) empty lane; (5) genomic DNA from the transgenic tree. PCR was performed with two internal $A c$ primers, $A c 1$ and $A c 2$.

We have presented a series of evidence, based on the GUS reporter gene, Southern blotting, PCR, reverse transcriptase, and transposon display showing that $A c$ is active in citrus plants (see Fig. 7). The behavior of $A c$ is similar in citrus and tomato (Yoder, 1990), namely, the element is not silenced and can actively proliferate. This contrasts with other plant species where $A c$ element proliferation is limited by negative dosage or methylation, e.g., maize or arabidopsis (Kunze and Weil, 2002). Moreover, we showed for the first time that $A c$ activity is maintained for a period of 4 years in the somatic body of a plant. These data indicate that the $A c$ system is ideally suited for high-throughput mutagenesis

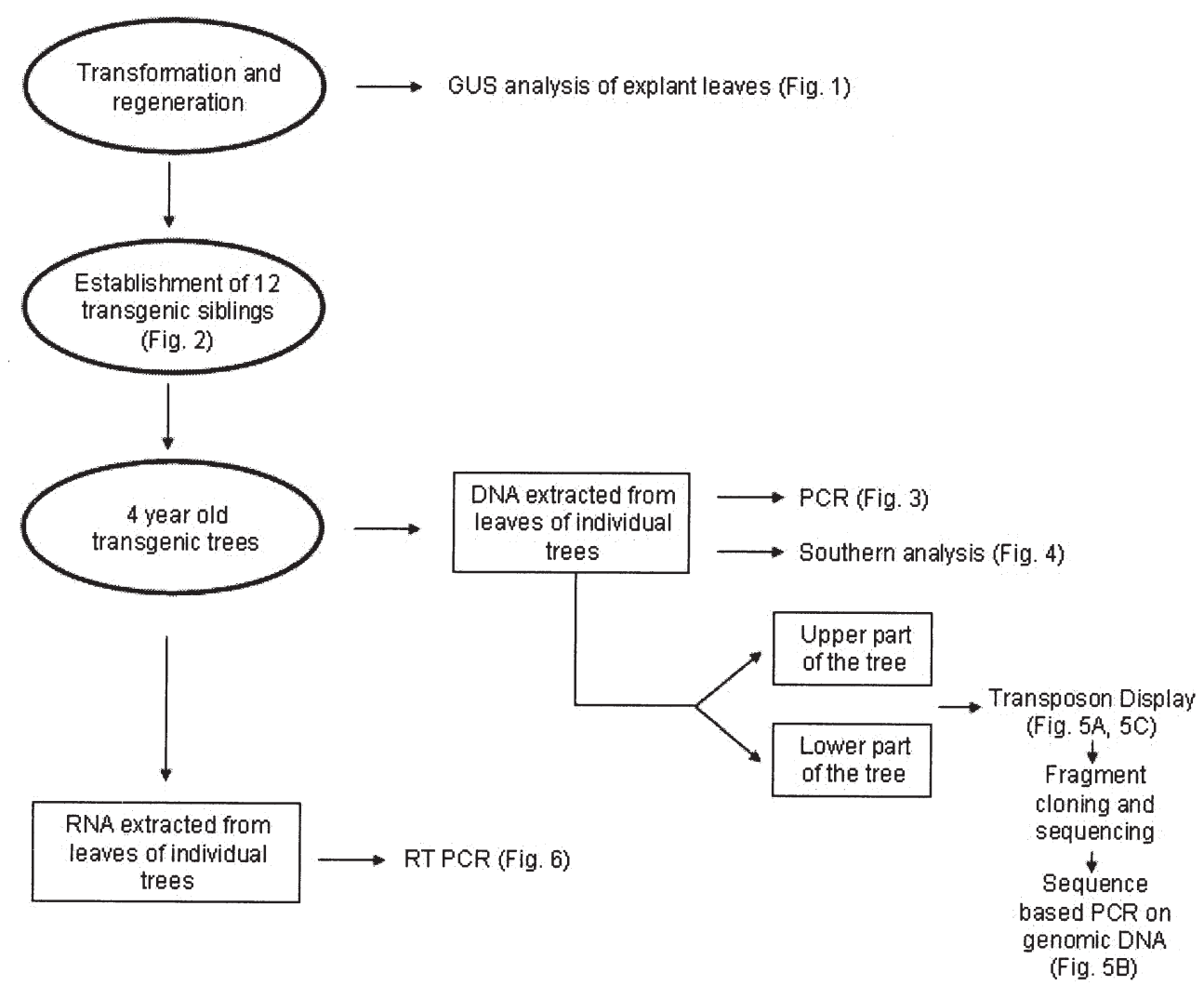

Fig. 7. Chronological outline of experimental procedures done with transgenic citrus plants. 
in citrus. Transformation of citrus is a laborious task. An active transposon system such as $A c$ in citrus makes it possible to generate, by vegetative propagation, a large population of tagged mutants starting from a few initial transgenic plants.

In this study, the "wild type" Ac element was used. A disadvantage of this element is that its transposition cannot be controlled. Based on the data obtained here, it is now worth investing the effort to generate a new generation of $A c$-derived transposons for functional genomics in citrus. Ideally, proliferation of these elements can be controlled, e.g., through inducibility of the transposase promoter, or through a two-element, $A c / D s$ system and dominant gain-of function mutants might be obtained. This work constitutes a basis to devise new powerful tools for forward and reverse genetics in citrus and other perennial plants.

\section{Literature Cited}

Baker, B., J. Schell, H. Lorz, and N.Y. Federoff. 1986. Transposition of the maize controlling element Activator in tobacco. Proc. Natl. Acad. Sci. USA 83:4844-4848.

Casa, A.M., C. Brouwer, A. Nagel, L. Wang, Q.Zhang, S. Kresovich, and S.R. Wessler. 2000. The MITE family Heartbreaker (Hbr): Molecular marker in maize. Proc. Natl. Acad. Sci. USA 97:10083-10089.

Ebinuma, H., K. Sugita, E. Matsunaga, and M. Yamakado. 1997. Selection of marker-free transgenic plants using the isopentenyl transferase gene. Proc. Natl. Acad. Sci. USA 94:2117-2121.

Finnegan, E.J., B.H. Taylor, S. Craig, and E.S. Dennis. 1989. Transposable elements can be used to study cell lineages in transgenic plants. Plant Cell 1:757-764.

Fladung, M. and M.R. Ahuja. 1997. Excision of the maize transposable element $A c$ in periclinical chimeric leaves if $35 \mathrm{~S}-A c$-rolC transgenic aspen-Populus. Plant Mol. Biol. 33:1097-1103.

Jefferson, R.A., T.A. Kavanagh, and M.W. Bevan. 1987. GUS fusions: B-Glucuronidase as a sensitive and versatile gene fusion marker in higher plants. EMBO J. 6:3901-3907.

Kumar, S. and M. Fladung. 2003. Somatic mobility of the maize element $A c$ and its utility for gene tagging in aspen. Plant Mol. Biol. 51:643-650.

Kunze, R. and C.F. Weil. 2002. The $h A T$ and CACTA superfamilies of plant transposons, p.565-610. In: N. Craig, R.M. Craigie, M. Gellert, and A. Lambowitz (eds.). Mobile DNA II. ASM Press, Washington, D.C.

Luth, D. and G. Moore. 1999. Transgenic grapefruit plants obtained by Agrobacterium tumefaciens-mediated transformation. Plant Cell Tissue Organ Cult. 57:219-222.

Martiessen, R.A. 1998. Functional genomics: Probing plant gene function and expression with transposons. Proc. Natl. Acad. Sci. USA 95:2021-2026.

Meissner, R., V. Chague, Q. Zhu, E. Emmanuel, Y. Elkind, and A.A. Levy. 2000. A high throughput system for transposon tagging and promoter trapping in tomato. Plant J. 22:265-274.

Murray, M.G. and W.F. Thompson. 1980. Rapid isolation of high molecular weight plant DNA. Nucleic Acid Res. 8:4321-4325.

Peña, L., M. Cervera, J. Juárez, A. Navarro, C. Ortega, J.A. Pina, N. Durán-Vila, and L. Navarro. 1996. Agrobacterium-mediated transformation and regeneration of Citrus. Proc. Intl. Soc. Citricult. 2:871-876.

Pereira, A. 2000. A transgenic perspective on plant functional genomics. Transgenic Res. 9:245-260.

Sambrook, J., E.F. Fritsch, and T. Manniatis. 1989. Molecular cloning: A laboratory manual, 2nd ed. Cold Spring Harbor Lab. Press, Cold Spring Harbor, N.Y.

Seidman, J. and K. Struhl. 1987. Phenol/SDS method for plant RNA preparation. Unit 4.3 In: F.M. Ausubel, R. Brent, R.E. Kingston, D.D. Moore, and J.A. Smith (eds.). Current protocols in molecular biology. Wiley, New York.

Van den Broeck, D., T. Maes, M. Sauer, J. Zethof, P. De Keukeleire, M. D'Hauw, M. Van Montague, and T. Gerats. 1998. Transposon display identifies individual transposable elements in high copy number lines. Plant J. 13:121-129.

Van Sluys, M.A., J. Tempe, and N.Y. Federoff. 1987. Studies on the introduction and mobility of the maize activator in Arabidopsis thaliana and Daucus carota. EMBO J. 6:3881-3889.

Vos, P., R. Hogers, M. Bleeker, M. Reijans, T. Van de Lee, M. Hornes, A. Frijters, J. Pot, J. Peleman, M. Kuiper, and M. Zabeau. 1995. AFLP: A new technique for DNA fingerprinting. Nucleic Acids Res. 23:4407-4414.

Yoder, J.I., J. Palys, K. Alpert, and M. Lassner. 1988. Ac transposition in transgenic tomato plants. Mol. General Genet. 213:291-296.

Yoder, J.I. 1990. Rapid proliferation of the maize transposable element Activator in transgenic tomato. Plant Cell 2:723-730. 